\title{
Gas-liquid chromatographic measurement of lignocaine in small samples of canine myocardium after enzymatic digestion
}

\author{
DAVID W. HOLT, MARY LOIZOU, AND RICHARD K. H. WYSE ${ }^{1}$ \\ From the Poisons Unit, Guy's Hospital, London SE1 9RT, and the ${ }^{1}$ Department of Paediatric Cardiology, \\ Institute of Child Health, London WC1, UK
}

SUMMARY A method is described whereby lignocaine can be measured in small samples of canine myocardium. A proteolytic enzyme is used to digest the tissue, and the drug, together with an internal standard, is subsequently extracted into an organic solvent and measured by gas-liquid chromatography. The method is reproducible using tissue samples as small as $\mathbf{5 0 ~} \mathrm{mg}$ and appears to be suitable for the measurement of a number of drugs in small samples of tissue.

Published methods for the measurement of lignocaine in animal tissues involve homogenisation before extraction of the drug into an organic solvent and subsequent gas-liquid chromatography (GLC) analysis (Svinhufvud et al., 1965; Ahmad and Medzihradsky, 1971; Benowitz and Rowland, 1973; Naito et al., 1977). Tissue samples of at least one gram were necessary with most of these methods (Svinhufvud et al., 1965; Ahmad and Medzihradsky, 1971; Benowitz and Rowland, 1973), although Naito et al. (1977) indicated that a sensitivity of $0.5 \mu \mathrm{g} / \mathrm{g}$ could be achieved if samples of approximately $0.3 \mathrm{~g}$ were used. However, in this latter method no lignocaine concentrations in muscle tissue were reported. Two of these methods included a solvent evaporation step (Ahmad and Medzihradsky, 1971; Naito et al., 1977), while Svinhufvud et al. (I965) did not use an internal standard. None of the above methods gives reproducibility data for lignocaine measurements in tissue samples, and only one (Naito et al., 1977) gives the limit of sensitivity for such measurements.

The method described here was developed for the measurement of lignocaine in small (100 $\mathrm{mg}$ or less) samples of myocardium resulting from the multiple sectioning of artificially produced infarcts in greyhounds, in an attempt to correlate the gradient of lignocaine concentrations across an infarct with cardiac blood flow; the results are being presented

Received for publication 29 August 1978 elsewhere (Wyse, R. K. H., Wittig, J. H., and Holt, D. W.-in preparation). The tissue was digested by a proteolytic enzyme, and lignocaine, together with an internal standard, was extracted into diethyl ether at an alkaline pH. Subsequently, these compounds were back-extracted into dilute acid and then reextracted into a small volume of chloroform, and a portion of the organic phase was analysed by GLC linked to flame ionisation detection.

\section{Material and methods}

\section{MATERIALS AND REAGENTS}

Crystalline lignocaine hydrochloride and monoethylglycinexylidide (MEGX) were obtained from Astra Chemicals, Watford, UK. Both chloroform and aqueous standards equivalent to $1 \mathrm{~g} / \mathrm{l}$ lignocaine free base were prepared. Crystalline mianserin hydrochloride (internal standard) was obtained from Organon Laboratories, Morden, UK and was used as either a $1 \mathrm{~g} / \mathrm{l}$ solution in chloroform or a $20 \mathrm{mg} / \mathrm{l}$ aqueous solution. Crystalline lyophilised Subtilisin Carlsburg (Bacterial A1 Proteinase EC 3.4.4.14) was purchased from Digby Chemicals, Richmond, UK with an assayed activity of $100 \times 10^{4}$ PUN. It was used as a $30 \mathrm{~g} / 1$ solution in $1 \mathrm{~mol} / 1 \mathrm{tris}$ (hydroxymethyl) aminomethane (pH 9-0). $\gamma$-glycidoxypropyltrimethoxysilane (A-187) was obtained from H. S. Chromatography Packings, Bourne End, UK. Diethyl ether, chloroform, sodium hydroxide, and sulphuric acid were all analytical reagent grade; the two latter compounds were used as $2 \mathrm{~mol} / \mathrm{l}$ and $0.25 \mathrm{~mol} / 1$ aqueous solutions, respectively. 
GAS CHROMATOGRAPHY

A Pye Series 104 model 24 gas chromatograph equipped with a flame ionisation detector and linked to a $1 \mathrm{mV}$ recorder was used. The detector and column oven temperatures were $250^{\circ}$ and $195^{\circ}$ respectively; an injection block heater was not used. The nitrogen (carrier gas) flow rate was $60 \mathrm{ml} / \mathrm{min}$ and the flame was supplied by oxygen and hydrogen at inlet pressures of 10 and $15 \mathrm{psi}$, respectively, giving flow rates of approximately 200 and $60 \mathrm{ml} / \mathrm{min}$. A $2.8 \mathrm{~m}$ coiled glass column with an internal diameter of $4 \mathrm{~mm}$ was silanised by filling with $2 \%$ dichlorodimethylsilane in toluene for one hour and subsequently was rinsed in methanol and dried at $100^{\circ}$. The column was packed with $3 \% \mathrm{OV}-101$ on $80-100$ mesh Supelcoport, purchased ready prepared from Chromatography Services, Merseyside, UK. The packed column was conditioned at $225^{\circ}$ with a nitrogen flow of $60 \mathrm{ml} / \mathrm{min}$ for 15 hours. The conditioned column was deactivated by injection of $20 \mu \mathrm{l}$ A-187; subsequently, $5 \mu \mathrm{l}$ injections of this compound were made at weekly intervals (Rutherford and Flanagan, 1978).

The chromatography of a chloroform solution containing both lignocaine and mianserin on this system is illustrated (Fig. 1).

\section{TISSUE DIGESTION}

To a pre-weighed $10 \mathrm{ml}$ tapered glass test-tube about $100 \mathrm{mg}$ wet weight of tissue were added and the

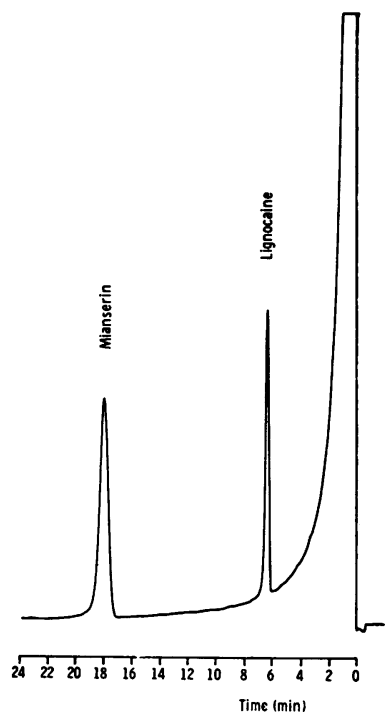

Fig 1 Chromatogram obtained on analysis of a solution of lignocaine $(10 \mathrm{mg} / \mathrm{l})$ and mianserin $(20 \mathrm{mg} / \mathrm{l})$ in chloroform; 5 ul injection. exact weight was determined. Enzyme solution $(1.5 \mathrm{ml})$ was added to the tube, which was then sealed with a ground-glass stopper and incubated at $45^{\circ}$ for 15 hours. Subsequently, the contents of the tube were vortex mixed to yield a homogeneous suspension.

\section{EXTRACTION PROCEDURE}

To $500 \mu \mathrm{l}$ of tissue digest in a $10 \mathrm{ml}$ tapered glass tube $100 \mu \mathrm{l}$ sodium hydroxide solution, $50 \mu \mathrm{l}$ aqueous mianserin hydrochloride, and $5 \mathrm{ml}$ diethyl ether were added.The tube was sealed with a ground glass stopper, and the contents were vortex mixed for 30 seconds and centrifuged in a windshielded instrument at $1800 \mathrm{~g}$ for 5 minutes. The ether extract was transferred by aspiration to a second tapered glass tube containing $500 \mu l$ sulphuric acid. The contents of this tube were similarly vortex mixed and centrifuged, the organic layer was removed by aspiration, and any residual solvent was eliminated under a stream of air. The solution was made basic by the addition of $300 \mu$ l sodium hydroxide solution, and $50 \mu \mathrm{l}$ chloroform was added. After vortex mixing for 15 seconds, the contents of this tube were centrifuged at $1800 \mathrm{~g}$ for 4 minutes, and a $5 \mu l$ portion of the organic phase was injected onto the column of the gas chromatograph. Each tissue digest was extracted in duplicate.

INSTRUMENT CALIBRATION

Standard solutions of lignocaine hydrochloride in chloroform were prepared by dilution of the $1 \mathrm{~g} / 1$ solution; these standards were equivalent to 5,10 , and $20 \mathrm{mg} / 1$ lignocaine free base. Each standard solution contained the equivalent of $20 \mathrm{mg} / \mathrm{l} \mathrm{mian}$ serin hydrochloride, obtained by dilution of the $1 \mathrm{~g} / \mathrm{l}$ solution. A linear calibration graph with zero intercept was obtained on analysis of these solutions.

\section{RECOVERY OF LIGNOCAINE FROM TISSUE} DIGEST

Myocardial tissue was obtained from a greyhound which had not been exposed to lignocaine. Aliquots of the aqueous $1 \mathrm{~g} / 1$ lignocaine solution were added to the digested tissue from this sample to yield standard lignocaine preparations in the range $0.5-2.0 \mathrm{mg} / \mathrm{l}$. These were analysed in the same manner as tissue homogenates and, since the procedure involves a 10:1 concentration step, the results were directly comparable with the chloroform standards in the range $5-20 \mathrm{mg} / \mathrm{l}$. The recovery of added lignocaine was determined by comparison of the calibration graph produced by the standards in digested tissue with that produced by the standards in chloroform. 
Results

Chromatograms obtained on analysis of an extract of a blank tissue sample and of a tissue sample

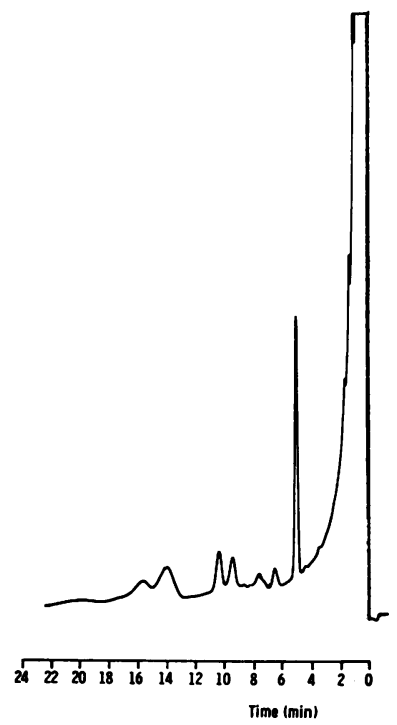

Fig. 2 Chromatogram obtained on analysis of a digest of drug-free canine myocardium; 5 l injection.

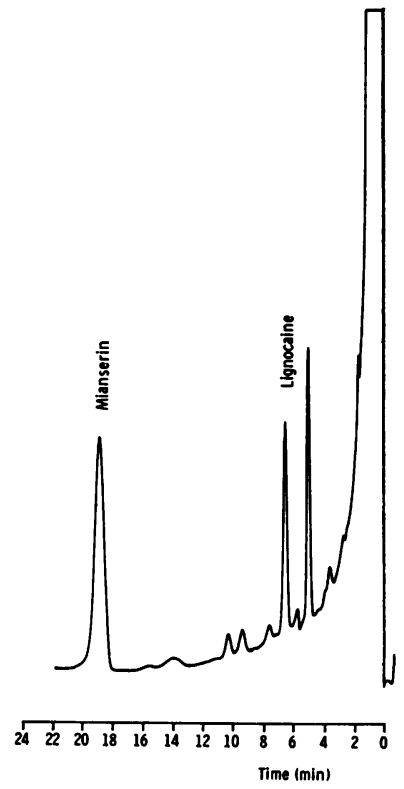

Fig. 3 Chromatogram obtained on analysis of a digest of canine myocardium containing lignocaine; $5 \mu l$ injection. The tissue concentration of lignocaine was $9.6 \mu \mathrm{g} / \mathrm{g}$ wet weight of tissue. containing lignocaine are illustrated in Figs 2 and 3, respectively.

No endogenous substances have been observed which could interfere in the analysis, and the retention time of MEGX relative to mianserin on this system was $\mathbf{0} \cdot 27$. The recovery of lignocaine added to lignocaine-free digested greyhound myocardium was $89 \% \pm 5.6$ (SD) across the concentration range $0.5-2.0 \mathrm{mg} / \mathrm{l}(\mathrm{n}=9)$. Accordingly, the results of tissue analyses were calculated by comparing the peak height ratio in the sample with the standard calibration graph produced by the analysis of the chloroform standards, and applying a recovery factor of $1 \cdot 12$. If the difference between duplicate analyses was greater than $10 \%$ the analysis was repeated. The final result was expressed in terms of $\mu \mathrm{g}$ lignocaine/g wet weight of tissue.

The reproducibility of both the assay and sampling technique was assessed by digesting several pieces of tissue from selected regions of an infarct. Tissue containing high, intermediate, and low concentrations of lignocaine were chosen, and up to eight pieces of each were digested and then analysed in duplicate. The results are summarised in Table 1.

Table 1 Reproducibility of lignocaine measurements

\begin{tabular}{lllll}
\hline $\begin{array}{l}\text { Tissue } \\
\text { sample }\end{array}$ & $\begin{array}{l}\text { Tissue weight } \\
(\mathrm{mg}) \\
(\mathrm{mean} \pm S D)\end{array}$ & $\begin{array}{l}\text { Range of } \\
\text { weights }(\mathrm{mg})\end{array}$ & $\begin{array}{l}\text { Lignocaine } \\
\text { concentration } \\
(\mu g / g \text { wet weight }) \\
(\text { mean } \pm S D)\end{array}$ & $\begin{array}{l}C V \\
\%\end{array}$ \\
\hline 1 & $85 \cdot 7 \pm 17.4$ & $\begin{array}{l}64 \cdot 3-110 \cdot 1 \\
(\mathrm{n}=8)\end{array}$ & $18 \cdot 1 \pm 1 \cdot 1$ & $6 \cdot 1$ \\
2 & $59 \pm 14.8$ & $\begin{array}{l}48 \cdot 8-82.6 \\
(\mathrm{n}=6)\end{array}$ & $6.8 \pm 0.49$ & $7 \cdot 3$ \\
3 & $100 . \pm 28.9$ & $\begin{array}{l}59 \cdot 3-144 \cdot 2 \\
(\mathrm{n}=8)\end{array}$ & $4 \cdot 2 \pm 0.57$ & 13.5 \\
\hline
\end{tabular}

The limit of sensitivity for the assay was $1 \mu \mathrm{g} / \mathrm{g}$ wet weight in a $100 \mathrm{mg}$ sample, which was more than adequate for the range of concentrations encountered in normal myocardium through to the central area of an infarct (Table 2). The animal had received a bolus of $2 \mathrm{mg} / \mathrm{kg}$ lignocaine intravenously after the induction of infarction, followed by an infusion of $5 \mathrm{mg} / \mathrm{kg} / \mathrm{h}$ for 45 minutes; the samples were collected at the cessation of this infusion. The blood concentration of lignocaine, measured by a specific GLC method (Holt et al., 1979), was $3 \cdot 8 \mathrm{mg} / 1$.

Table 2 Typical lignocaine concentrations in canine myocardium samples

\begin{tabular}{lll}
\hline Tissue sample & $\begin{array}{l}\text { Sample weight } \\
(\mathrm{mg})\end{array}$ & $\begin{array}{l}\text { Tissue lignocaine } \\
\text { concentration } \\
(\mu \mathrm{g} / \mathrm{g} \text { wet weight })\end{array}$ \\
\hline Normal myocardium & $100 \cdot 6$ & $13 \cdot 9$ \\
Peri-infarct zone & $77 \cdot 1$ & $6 \cdot 7$ \\
Central infarct zone & $100 \cdot 1$ & $3 \cdot 2$ \\
\hline
\end{tabular}




\section{Discussion}

In order that subtle changes in lignocaine concentration within the infarct zone might be measured the samples to be measured by this method were, of necessity, small. It was felt that the published methods would result in an unacceptable loss of tissue during homogenisation, and furthermore, details of sensitivity and reproducibility for these methods were lacking.

Use of the enzyme Subtilisin Carlsburg for the digestion of tissue before the extraction and measurement of drugs was described by Osselton et al. (1977), who partially digested liver containing benzodiazepines using substantially lower concentrations of enzyme than in our method. However, it was found that the reproducibility of the present method was poor unless the tissue was digested to form a uniform suspension. For tissue samples in the range $50-150 \mathrm{mg}$, this was achieved only with high concentrations of enzyme. Osselton et al. (1977) reported a considerably higher recovery of benzodiazepines from liver samples subjected to enzymatic digestion compared with the same samples treated by acid hydrolysis. Similarly, our results for the concentration of lignocaine in normal canine myocardium are much higher than those reported by Ahmad and Medzihradsky (1971), who analysed tissue from dogs receiving comparable doses of the drug using tissue homogenisation. This discrepancy cannot be accounted for by either the release of lignocaine from conjugates, since this is not a pathway associated with its metabolism, or interference from the metabolite MEGX. It is possible that extraction of these drugs is more complete after disruption of the tissue by enzymatic digestion.

Our experience with this method suggests that it could easily be adapted for the precise measurement of other drugs in very small tissue samples when the use of blenders or homogenisers might result in a variable loss of tissue. Applications could include kinetic studies involving the uptake of drugs by tissues and the forensic investigation of small tissue samples.
We are grateful to Astra Chemicals, Watford, UK for the gifts of lignocaine hydrochloride and MEGX, and to Organon Laboratories, Morden, UK for the gift of mianserin hydrochloride. DWH thanks Dr M. D. Osselton, Home Office Research Establishment, Aldermaston, UK for his expert advice, and we thank Mr R. J. Flanagan for helpful criticism of the manuscript.

\section{References}

Ahmad, K., and Medzihradsky, F. (1971). Distribution of lidocaine in blood and tissues after single doses and steady infusion. Research Communications in Chemical Pathology and Pharmacology, 2, 813-828.

Benowitz, N., and Rowland, M. (1973). Determination of lidocaine in blood and tissues. Anesthesiology, 39, 639-641.

Holt, D. W., Flanagan, R. J., Hayler, A., and Loizou, M. (1979). A simple gas-liquid chromatographic method for the measurement of mexiletine and lignocaine in blood-plasma or serum. Journal of Chromatography (in press).

Naito, E., Matsuki, M., and Shimoji, K. (1977). A simple method for gas chromatographic determination of lidocaine in tissues. Anesthesiology, 47, 466-467.

Osselton, M. D., Hammond, M. D., and Twitchett, P. J. (1977). The extraction and analysis of benzodiazepines in tissues by enzymic digestion and high-performance liquid chromatography. Journal of Pharmacy and Pharmacology, 29, 460-462.

Rutherford, D. M., and Flanagan, R. J. (1978). Rapid micro-method for the measurement of phenobarbitone, primidone and phenytoin in blood-plasma or serum by gas-liquid chromatography. Journal of Chromatography, 157, 311-320.

Svinhufvud, G., Örtengren, B., and Jacobsson, S. E. (1965). The estimation of lidocaine and prilocaine in biological material by gas chromatography. Scandinavian Journal of Clinical and Laboratory Investigation, 17, 162-164.

Requests for reprints to: Dr D. W. Holt, Poisons Unit, Guy's Health District, New Cross Hospital, Avonley Road, London SE14 5ER, UK. 